\title{
EROS FOR ANNABELLE
}

\section{Love's labour.}

\section{BY IAN WHATES}

I never liked Annabelle. During one particularly heated exchange, Josh snapped that my animosity was born of jealousy. That hurt; in part because he probably had a point. Annabelle was gorgeous, intelligent, witty, charming, vindictive, manipulative, ambitious and calculating. I could see all of that. Josh, naturally, could see only half of it. What mother wouldn't be envious of such a woman ... particularly when her son's heart had been stolen away? And he was all I had left.

Annabelle latched onto Josh because he was a genius, and abandoned him when it became apparent that his brilliance would never bring the commercial, the financial success she craved. At first she worked hard on his behalf, I'll grant her that much; but, despite all the doors that her striking looks and social connections could open, Josh's talent proved too abstract and too elusive.

Given the uncertainty of the still-emerging economy, we all longed for some security; but Annabelle more than most. Inevitably she caught the eye of someone wealthy and influential, transferring her affections in a flash and slipping into this new relationship as if it were a natural progression: social evolution in action. Josh was devastated, as was I, by proxy. I hated Annabelle with a vengeance, but I hated what her loss did to my son even more.

Faced with an impossible choice, I chose the unthinkable: encouraging him to try to win her back.

Of course, it was never going to be that easy. Did I mention that Annabelle was vindictive? She set him a challenge. Presumably she found the prospect of his scrabbling around in a desperate, futile attempt to impress her amusing. It wasn't because she expected or wanted him to succeed, that much is certain. After all, the challenge she set him was impossible, but he wouldn't refuse - couldn't refuse.

Eros: that was what she wanted. Annabelle had worked in London before the Downfall and kept eulogizing the place: Shangri-La with added fairy dust to hear her speak of it. To prove his love for her, she demanded that my son recreate a tiny piece of her precious London: the

\section{$\rightarrow$ NATURE.COM}

Follow Futures:

@NatureFutures

f go.nature.com/mtoodm

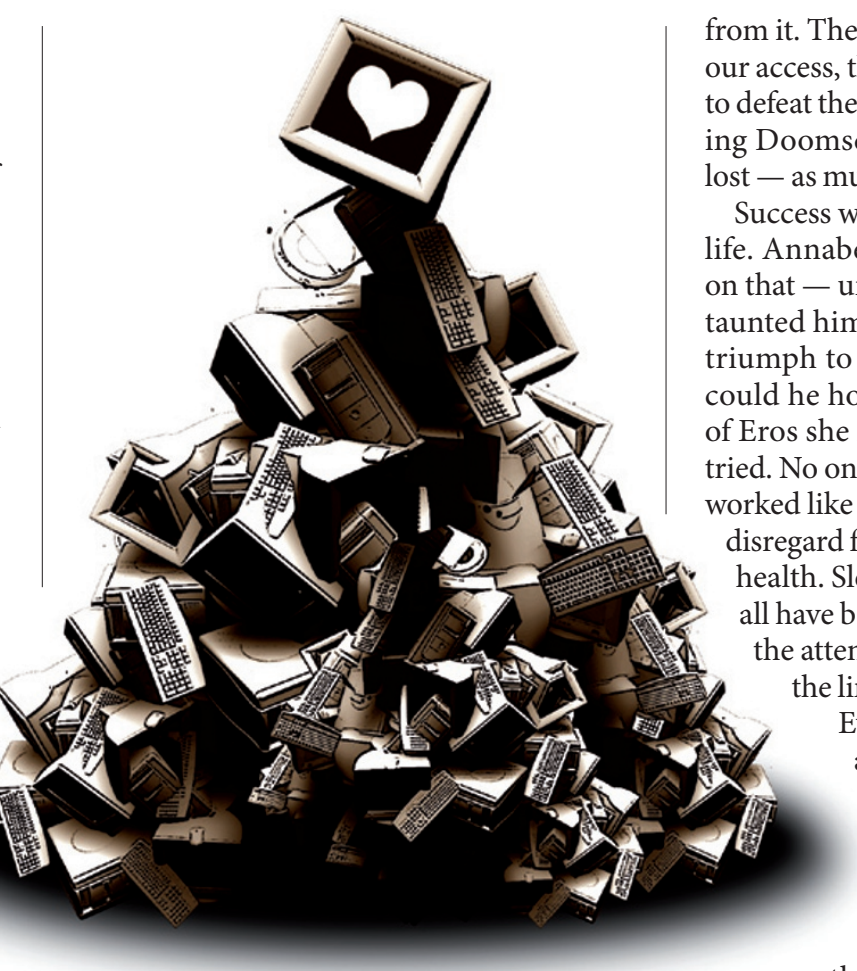

from it. The Downfall viruses are blocking our access, that's their purpose; and mine is Deat them, to find a way of circumventday and regaining what we ve - as much of it as possible, at any rate."

Success would ensure that he was set for abelle knew that - had counted him, insisting he produce instant to order. Only with a computer e to build the $3 \mathrm{D}$ renderin one could have strived harder. $\mathrm{He}$ a man possessed, with reckles disregard for his own physical and mental ealth. Sleep, food, hygiene, they would been neglected entirely if not for attentions of a worried mother and e limits of human endurance.

Even so, he failed. In frustration and the anguished conviction that he was close... Christmas and New Year came and went, as did Annabelle. An exhausted Josh had a breakdown. I feared for him then, feared that he would never recover. But in time he did, thanks to corner of Piccadilly Circus where the famous statue of Eros, God of Love, once stood. She gave him until New Year's Eve. Fail, and he would lose her forever.

The whole thing doubtless struck her as deliciously ironic: love for love; and at $\mathrm{New}$ Year too, which was, of course, the last great celebration; the last joyous time that anyone could remember from the Old World. Downfall had come in January - the fiery destruction of the cities and the collapse of the Internet: the end of a civilization we'd all so blithely taken for granted.

No one knew who started it and no one cared, not any more. People's horizons had narrowed dramatically. They had to. It was that or perish. The 'Downfall Virus' - a misnomer as Josh kept telling me - destroyed the Internet and rendered every computer useless. It wasn't really a single virus, Josh claimed, but a multitude of nanotech that kept replicating, adapting and mutating. Everything seemed to be infected: even isolated computers that had never been linked to the net would crash and go into meltdown without warning. I didn't understand how it worked, but Josh did. That was his genius.

"All the information that existed on the net, it's not really gone," he once told me. "It's out there somewhere, but we're being kept the patience and love of Jasmine, who is everything that Annabelle could never be. Did I mention that my son is a genius? He returned to work, succeeding as I always knew he would.

Doomsday is still with us but it's manageable now. We're learning to cope, thanks to Josh. And, drawing on a rudimentary, partially reclaimed Internet, he finally built his Eros, inspired by someone who is worthy of such a tribute, a woman who is everything that a mother could hope for. He's famous now, and happy, and wealthy beyond Annabelle's wildest dreams.

Want to hear the funny part? The statue which that bitch drove Josh to recreate was never really of Eros at all, though that's what everyone called it back in the Old World. It was actually of Anteros, Eros' brother. They both numbered among the Erotes, the ancient Greeks' Gods of Love, but Anteros was a very specific god. He was the Avenger of Unrequited Love. It would seem that Annabelle knew less about irony than she supposed.

Ian Whates is the author of the Noise books (Solaris) and the City of 100 Rows trilogy (Angry Robot). His second collection, Growing Pains, is due from PS Publishing in April 2013. 